\title{
Effects of luxury brand perceptions on brand attachment and purchase intention: A comparative analysis among consumers in China, Hong Kong and Taiwan
}

\begin{tabular}{|c|c|}
\hline \multicolumn{2}{|c|}{$\begin{array}{l}\text { Authors: } \\
\text { Te-Hsing Ku } \\
\text { Tzu-Ling } \operatorname{Lin}^{1}\end{array}$} \\
\hline \multicolumn{2}{|c|}{$\begin{array}{l}\text { Affiliations: } \\
{ }^{1} \text { Department of Textiles } \\
\text { and Clothing, Fu Jen Catholic } \\
\text { University, Taiwan, Republic } \\
\text { of China }\end{array}$} \\
\hline \multicolumn{2}{|c|}{$\begin{array}{l}\text { Corresponding author: } \\
\text { Te-Hsing Ku, } \\
\text { 077637@mail.fju.edu.tw }\end{array}$} \\
\hline \multicolumn{2}{|c|}{$\begin{array}{l}\text { Dates: } \\
\text { Received: } 27 \text { Mar. } 2017 \\
\text { Accepted: } 02 \text { Aug. } 2017 \\
\text { Published: } 13 \text { June } 2018\end{array}$} \\
\hline \multicolumn{2}{|c|}{$\begin{array}{l}\text { How to cite this article: } \\
\text { Ku, T-H. \& Lin, T-L., 2018, } \\
\text { 'Effects of luxury brand } \\
\text { perceptions on brand } \\
\text { attachment and purchase } \\
\text { intention: A comparative } \\
\text { analysis among consumers } \\
\text { in China, Hong Kong and } \\
\text { Taiwan', South African Journal } \\
\text { of Business Management } \\
\text { 49(1), a6. https://doi.org/ } \\
\text { 10.4102/sajbm.v49i1.6 }\end{array}$} \\
\hline \multicolumn{2}{|c|}{$\begin{array}{l}\text { Copyright: } \\
\text { (c) 2018. The Authors. } \\
\text { Licensee: AOSIS. This w } \\
\text { is licensed under the } \\
\text { Creative Commons } \\
\text { Attribution License. }\end{array}$} \\
\hline \multicolumn{2}{|l|}{ Read online: } \\
\hline 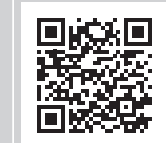 & $\begin{array}{l}\text { Scan this QR } \\
\text { code with your } \\
\text { smart phone or } \\
\text { mobile device } \\
\text { to read online. }\end{array}$ \\
\hline
\end{tabular}

The purpose of this study was to investigate the relationship among luxury brand perceptions (i.e. individual value, social influence and luxury brand image), luxury brand attachment and luxury brand purchase intention. In addition, the study examines the influence of antecedents on brand attachment and purchase intention among consumers in China, Hong Kong and Taiwan (i.e. the Greater China region). Using an empirical research method, the effects of luxury perceptions on brand attachment and purchase intention are tested using the partial least squares (PLS) approach to structural equation modelling. Differences in the structural relationship among subsamples were also examined by multi-group analysis to achieve a better understanding of the characteristics of different markets, thus contributing to the marketing strategy knowledge. According to the study results, antecedents, including individual value, social influence and luxury brand image, significantly influence brand attachment and purchase intention. Furthermore, the group comparisons suggest that the three subsamples have different characteristics with respect to the structural relationship. In the China subsample, brand attachment is more likely to be influenced by social influence. In comparison, Hong Kong consumers are more rational, that is, brand attachment and purchase intention are strongly influenced by consumer's perception of luxury brand image. Finally, the purchase intention of Taiwanese consumers mainly depends on the affection for the luxury brand.

\section{Introduction}

In the fashion and luxury goods market, competition among brands is fierce. Creating values and an irreplaceable status in the minds of consumers are unique brand management strategies found in the luxury industry. More precisely, as luxury brands succeed in developing the consumer's brand attachment, they create what is termed brand love and thus ensure continuing profit for the brands (Carroll \& Ahuvia 2006).

Brand attachment describes the strength of the bond that connects consumers with brands. This attachment is critical because it affects the behaviour that fosters brand profitability and consumer lifetime value (Thomson, MacInnis \& Park 2005). Brand attachment creates a commitment between consumers and brands, which can evolve into a long-term relationship between consumers and brands and between subsequent commitment behaviours, such as brand loyalty, of consumers (Ahluwalia, Burnkrant \& Unnava 2000) and the unwillingness to replace one brand with another (Park, MacInnis \& Priester 2006). The main purpose of this study was to investigate the relationship between brand attachment, purchase intention and the described antecedents.

With continuous, dynamic growth, the luxury market is now characterised by the provision of a broader availability to consumers than ever before (Wiedmann, Hennigs \& Klarmann 2012). In recent years, there has been an increase in the consumption of luxury goods across Asia. The consumption of luxury goods is no longer restricted to wealthy consumers from the country of origin of the goods for most luxury brands. Today, nearly all global luxury brands have entered the Chinese market. To succeed in China, it is important to gain knowledge of the Chinese consumer market.

An increasing number of empirical studies have assessed the attitude and enthusiasm of Chinese consumers towards luxury brands. Most studies have primarily focused on consumer segmentations 
and the consumption motives, drivers and behaviours of affluent consumers (Gao et al. 2009; Li, Li \& Kambele 2012; Wang, Sun \& Song 2010). As for the Chinese market, we have been paying attention to Greater China - China, Hong Kong and Taiwan. These three regions are experiencing social and economic development under very distinct circumstances and with different progress in the luxury industry. These differences have tremendous implications for the marketing strategy of luxury brands. Therefore, this study examines the influence of perceptive factors of consumers, such as individual value, social influence and brand image, on brand attachment and purchase intention. In addition, a multi-group analysis method is employed to examine group differences across China, Hong Kong and Taiwan to get more insights into the differences and provide suggestions for the luxury brand management.

\section{Influence of brand attachment on purchase intention}

Attachment is more than overt behaviour; it is internal and instinctive (Bowlby 1982). Attachment research in psychology focuses on interpersonal relationships, such as the attachment behaviour between infants and mothers, children and parents (Weiss 1988). In addition to the attachment between individuals, human beings can develop attachments to material objects, such as brands. Park et al. (2006) define brand attachment as a mental state that powerfully links personal emotion and perception with the brand, resulting in the individual viewing the brand as an extension of the self.

Conceptual properties of brand attachment can be reflected and measured through two key constructs: brand-self connection and brand prominence (Park et al. 2009). The brand-self connection is the cognitive and emotional link between an individual and a brand, which includes viewing the brand as a part of the self (Chaplin \& John 2005). Brand prominence refers to the ease and frequency with which brand-related thoughts can be triggered in consumers (Park et al. 2010). When these emotions and feelings are highly accessible, prominence could significantly influence decisions and ultimately affect the consumer's purchasing practices (Akçura, Gönül \& Petrova 2004).

Intent is the key element of consumer attitude and can be applied to predict actual behaviour. Purchase intention refers to the possibility of consumers purchasing a given product (Schlosser, White \& Lloyd 2006). The purchase intention is the evaluation of products and services made by consumers, which result in the possibility of a transaction (Zeithaml 1988). Obviously, consumers with positive purchase intentions will construct positive purchase commitments. The purchase intention is the most accurate indicator when predicting purchase behaviour.

Brand attachment accurately predicts intentions to perform behaviours and is a strong predictor of actual behaviours. Brand attachment serves as the ideal destination for the consumerbrand relationship (Parketal. 2010). Therefore, brand attachment may become the motive for a consumer's behaviour and function as an effective predictor of the consumer's behaviour, including actual consumption behaviour, brand purchase sharing, need sharing and the performance of difficult behaviour (Park et al. 2010). Generally, brand attachment can be defined as the strength of the cognitive and affective bond that connects the consumer with the brand. Stronger attachments reflect a stronger connection, passion and love, and brand attachment should be a key factor of consumer intention. Therefore, we posit the following hypothesis:

H1: Brand attachment positively influences purchase intention.

\section{Relationship of individual value and brand attachment}

Typically, values are not fluid and flexible. They tend to be relatively stable and enduring. In this study, individual value represents the consumer's personal view of luxury consumption, which can reflect self-identity, materialism and hedonism (Hennigs et al. 2012). Self-identity can be defined as the individual's subjective perception and private thoughts. Consumers may develop and integrate their identity through luxury items (Vigneron \& Johnson 2004). Materialistic value represents the individual's general materialistic orientation and desire for possessions. Consumers with highly materialistic orientations will have positive attitudes towards the acquisition of luxury goods and assign a high priority to material possessions. They may treat luxury brand products as intrinsically more valuable (Wiedmann, Hennigs \& Siebels 2009). Hedonism refers to sensory gratification, such as a feeling of pleasure and aesthetic enjoyment received from luxury products. In addition, the purchase and consumption of luxury brands may bring positive experiences, such as personal rewards and a sense of fulfilment (Vigneron \& Johnson 2004; Widemann et al. 2009).

Unlike typical consumer goods, luxury brands and products have groups of committed adherents who possess a strong value identification regarding the consumption of luxury products. The members of this group represent the targeted consumers of luxury brands and the consumer group that every luxury brand wishes to obtain and maintain. The importance of values is that they generally influence attitudes and behaviour. In addition, brand attachment originates when a brand enters a consumer's mind, creating a link between the brand and the consumer's self-concept (Park et al. 2010). Therefore, the intimate relationship between individual value and brand attachment is evident and might represent a crucial factor that influences the formation of brand attachment. Therefore, we posit the following hypothesis:

H2: Individual value positively influences brand attachment.

\section{Relationship between social influence and brand attachment}

Human beings live in societies and, therefore, will always be members of a community. Personal behaviour is restricted by customs and regulations and constantly influenced by social groups, such as family, peers, colleagues and other 
group members. Social influence primarily refers to the influences and restrictions of social regulations and social values on individuals. Often, these influences are more frequently observed in fashion-related industries than other industries. Luxury brands have always been viewed as representatives of the fashion industry. Therefore, external influence is even more notable when consumers purchase luxury goods. From a sociological perspective, social influence can be described as a social network. Mitchell (1969) defined 'social network' as specific connections between individuals within a group. This relationship structure can be used when explaining the social behaviour of individuals within a group. During the process of transmitting 'social network' messages, the familiarity between the receiver and the sender can be distinguished according to 'tie strength' (Brown \& Reingen 1987). Based on the degree of intimacy, interaction frequency and durability between the message receiver and sender, ties can be categorised into 'strong ties' and 'weak ties'. Strong ties are formed when the sender and the receiver are well acquainted, such as close friends or colleagues. Word-ofmouth propagation occurs more easily through these strong ties, which exert more influence during decision-making (Brown \& Reingen 1987; Wirtz \& Chew 2002). In contrast, weak ties refer to ties between acquaintances or strangers. The information of groups with weak ties has more diverse origins and is more multivariate. Generally, information with higher heterogeneity is more likely transmitted through weak ties. To provide a complete description of the effects of social influence on consumers, in this study, the concept of social network strength is combined with a measure of social influence, including the influences of strong and weak ties.

Consumers construct identifiable social images through consumption. Therefore, the marketing strategies of luxury brands emphasise the social meaning of their products. For instance, certain consumers purchase luxury brands to satisfy social salience. In the case of luxury brands, brands are treated as symbols of excellence and taste that fulfil the need for social identification, and representation with certain social groups that strengthen the individual's status within these groups (Sallot 2002). This phenomenon leads luxury brands to adopt marketing strategies that target the image of achievement and excellence to enhance the purchaser's sociality. In addition, Vigneron and Jonson (1999) revealed that cognitive values associated with prestige products could be influenced by others. Moreover, given that communication technology is highly developed and information transfer is convenient, the element of social influence is guaranteed to be an influence on the affection and desire felt regarding a brand. Thus, we posit the following hypothesis:

H3: Social influence has a positive and direct influence on brand attachment

\section{Relationships between luxury brand image, brand attachment and purchase intention}

Based on satisfying the needs of consumers, detailed divisions of the benefits and concepts of brands are functional image, experiential image and symbolic image (Park, Jaworski \& Maclnnis 1986). Functional image is related to actual benefits of consumption, such as products or services. Functional image is typically connected with the product's main attributes and often the satisfaction of the consumer's basic needs. In the case of luxury brands, functional image refers to the consumer's perception of the product, such as the product's material and design (Berthon et al. 2009). Next, experiential image implies the sensation of consumers when using products or availing services. Experiential image primarily describes the satisfaction that the product provides with respect to consumers' perceptions and desires. In the case of luxury products, the experiential image refers to sensory pleasure, the feeling of happiness and joy, and the encouragement and inspiration that the product provides to the consumer. Symbolic image refers to the attached benefits that consumers gain when consuming products or availing services, primarily the satisfaction of consumers' inner needs (Park et al. 1986).

Brand image is a brand association in a consumer's memory that has become the foundation for further assessment and response (Keller 1993). In the marketing of luxury brands, brand image is an important asset. Its construction and application can create premium effects for luxury brands, as well as profit and competitive advantages. Therefore, the consumer's attitude towards brand image is constructed of perceptive elements, such as the brand's functional, experiential and symbolic perception. The more positive the consumer's attitude towards the brand image is, the more positive the brand attachment and the higher the effect on purchase intention towards the luxury brand.

Thus, we posit the following hypotheses:

H4: Luxury brand image positively influences brand attachment.

H5: Luxury brand image positively influences purchase intention.

In summary, the formation of values and behaviour is primarily based on the individual's value system and perception and is internalised as a belief through the reference and application of external information. This study uses individual value and social influence as the antecedent variables that affect brand attachment. In addition, luxury brand image is a key antecedent that influences brand attachment and purchase intention. The proposed model with five hypotheses is presented in Figure 1.

\section{Method}

\section{Measurement}

The research model for this study contains five main constructs: individual value, social influence, luxury brand image, brand attachment and purchase intention. The scales used to measure the latent constructs are provided in Table 1. The items used as research variables in this study were adapted from prior research and modified to fit the luxury brand context of the study to increase the reliability and 


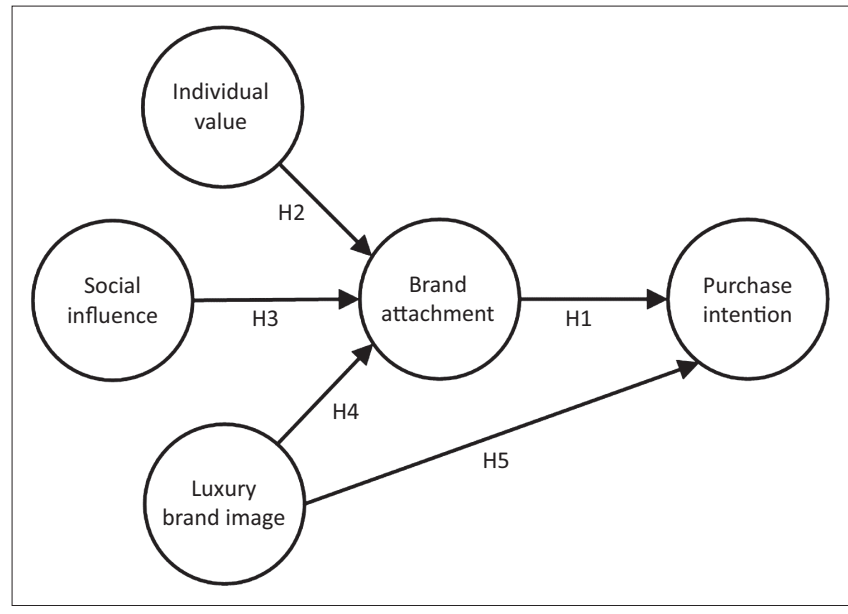

FIGURE 1: Conceptual model.

TABLE 1: Measurement scales.

\begin{tabular}{|c|c|c|}
\hline Constructs & Sub-constructs & Source \\
\hline \multirow[t]{3}{*}{ Individual value } & Self-identify value & \multirow[t]{3}{*}{ Based on Wiedmann et al. (2009) } \\
\hline & Materialistic value & \\
\hline & Hedonic value & \\
\hline \multirow[t]{2}{*}{ Social influence } & Strong ties influence & \multirow{2}{*}{$\begin{array}{l}\text { Based on Brown and Reingen } \\
\text { (1987) and Hennigs et al. (2012) }\end{array}$} \\
\hline & Weak ties influence & \\
\hline \multirow[t]{3}{*}{ Luxury brand image } & Functional image & \multirow{3}{*}{$\begin{array}{l}\text { Based on Park et al. (1986); } \\
\text { Hung et al. (2011) }\end{array}$} \\
\hline & Experiential image & \\
\hline & Symbolic image & \\
\hline \multirow[t]{2}{*}{ Brand attachment } & Brand-self connection & \multirow[t]{2}{*}{ Based on Park et al. (2010) } \\
\hline & Brand prominence & \\
\hline Purchase intention & - & $\begin{array}{l}\text { Based on Grewal, Monroe and } \\
\text { Krishnan (1998) }\end{array}$ \\
\hline
\end{tabular}

validity of the survey instrument. All the survey items were measured using a seven-point Likert scale.

\section{Data collection}

Based on a private customer database of a luxury brand, the survey link was sent to approximately 600 residents in Greater China (i.e. China, Hong Kong and Taiwan) who are actual consumers of luxury brands. The completed surveys of the respondents who had bought or received luxury merchandise during the previous year were retained. Of the 600 surveys that were distributed, 359 satisfied this criterion and thus were used for data analysis. Of the participants, $69.4 \%$ were women and $30.6 \%$ were men. In addition, $1.1 \%$ were younger than 20 years of age, $62.7 \%$ were between 20 and 30 years of age, $26.5 \%$ were between 31 and 40 years of age, and $9.7 \%$ were older than 40 years of age. The personal monthly discretionary income of the participants averaged approximately $8700 \mathrm{CNY}$ in the China subsample (sample size $=149), 7900 \mathrm{HKD}$ in the Hong Kong subsample (sample size $=105)$ and 27000 TWD in the Taiwan subsample (sample size $=105$ ).

\section{Data analysis and results}

To validate our research model, a survey method was used. We employed a partial least squares (PLS) regression to test our research model using Smart PLS 3.0. Partial least squares regression is a second-generation regression method that combines confirmatory factor analysis (CFA) with regression. It is the preferred method for multi-item constructs (Chin 1998). The main characteristics of PLS regression are the examination of the significance of the relationships between research constructs and the predictive power of the dependent variables. Therefore, PLS regression is suitable for examining applicability with theory building and prediction (Fornell \& Bookstein 1982; Fornell \& Cha 1994). Other advantages of PLS regression are a reduced requirement for normal distribution with the source data (Chin 1998; Gefen \& Straub 2005) and the ability to analyse a relatively small sample size (Barclay, Higgins \& Thompson 1995; Chin 1998).

We adopted a two-step analysis procedure to test the research model. Firstly, the assessment of the measurement model was performed to examine the reliability and validity of the measurement instrument. Then, the structural model was estimated to test the significance of the hypotheses and the predictive power of the research model.

\section{Measurement model}

In this study, we proposed a concept model with a secondorder hierarchy. From the results of CFA (Table 2), all of the items have sufficient loading under their respective construct. The composite reliabilities (CR) of all constructs were above 0.89, and the average variance extracted (AVE) for the constructs ranged from 0.75 to 0.80 . The item loadings, CR and AVE of the first-order and second-order measurement models exceeded the effective cut-off values of 0.7 for item loading, 0.7 for CR and 0.5 for the AVE. This outcome indicates that scale reliability and convergent validity were adequate (Fornell \& Larcker 1981; Hair et al. 2009).

In addition, to assess discriminant validity, this study calculated the square root of the AVE (Table 3), whereby the square root of the AVE should exceed the intercorrelations of the construct with the other constructs in the model (Chin 1998; Fornell \& Larcker 1981; Hulland 1999). In Table 3, none of the intercorrelations of the constructs exceeded the square root of the AVE of the constructs.

\section{Structural model}

Path analysis was performed by bootstrap (i.e. individual sign changes) with a sample number of 5000. Figure 2 summarises the path analysis results for our proposed model. The standardised regression coefficients are shown above each path. Overall brand attachment is significantly influenced by individual value (path coefficient $=0.152$ ), social influence (path coefficient $=0.338$ ) and luxury brand image (path coefficient $=0.402$ ), providing support for $\mathrm{H} 2$, $\mathrm{H} 3$ and $\mathrm{H} 4$. In addition, brand attachment (path $=0.432$ ) and luxury brand image (path $=0.437$ ) significantly affect purchase intention, and these results support $\mathrm{H} 1$ and $\mathrm{H} 5$. All of the hypotheses in our study are supported at a 0.05 confidence level.

Regarding the explanatory ability of the research model, the R-squared for brand attachment was approximately 0.614, 
TABLE 2: Confirmatory factor analysis results of the measurement model.

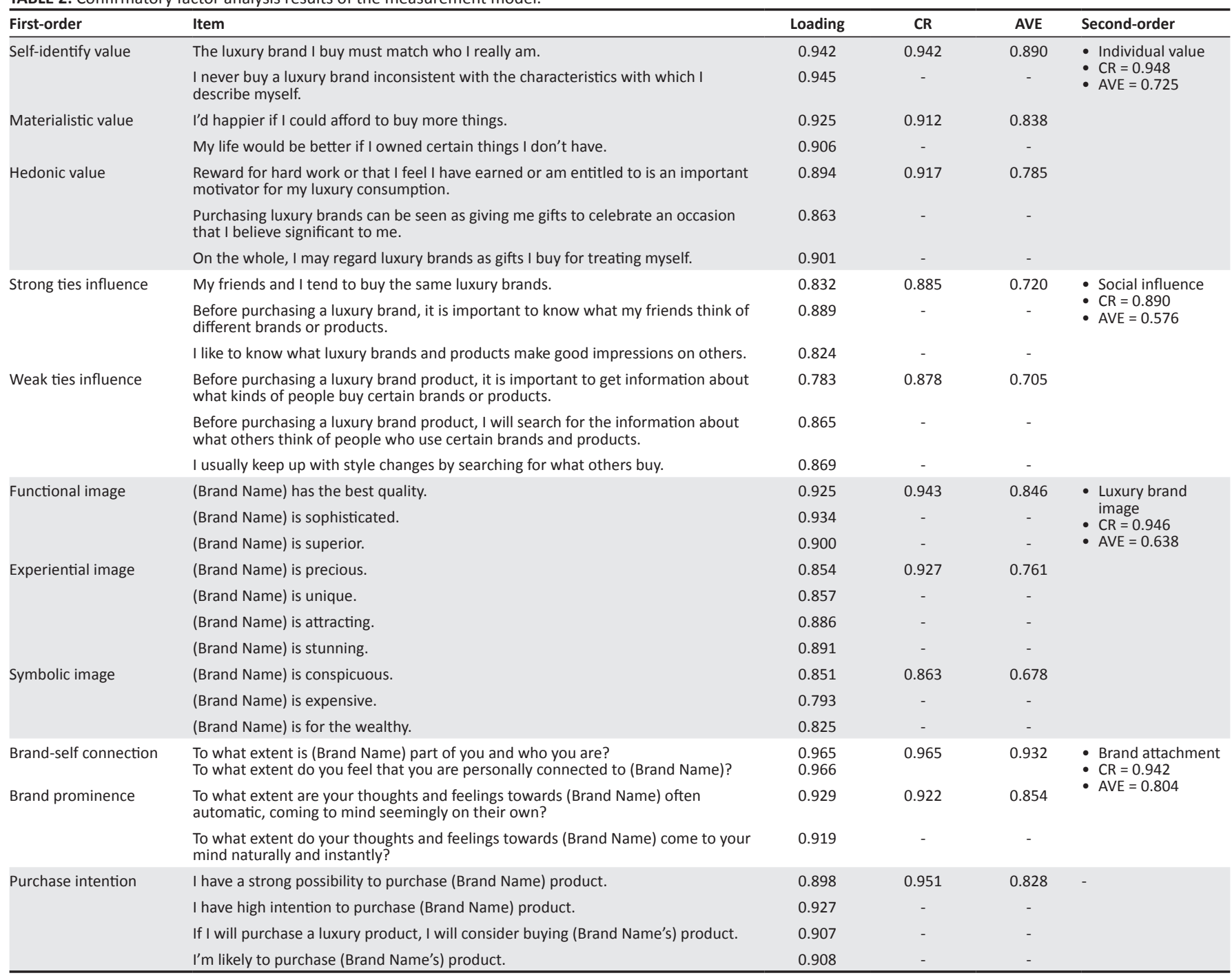

$\mathrm{CR}$, composite reliabilities; AVE, average variance extracted.

TABLE 3: Average variance extracted, square root of the average variance extracted (number in bold) and correlations among variables.

\begin{tabular}{|c|c|c|c|c|c|c|c|c|c|c|c|c|}
\hline First-order constructs & AVE & SV & MV & HV & SI & WI & FP & EP & SP & $\mathrm{BC}$ & BP & PI \\
\hline Self-identify value & 0.890 & 0.944 & - & - & - & - & - & - & - & - & - & - \\
\hline Materialistic value & 0.838 & 0.865 & 0.916 & - & - & - & - & - & - & - & - & - \\
\hline Hedonic value & 0.785 & 0.793 & 0.782 & 0.886 & - & - & - & - & - & - & - & - \\
\hline Strong ties influence & 0.720 & 0.573 & 0.642 & 0.604 & 0.849 & - & - & - & - & - & - & - \\
\hline Weak ties influence & 0.705 & 0.588 & 0.594 & 0.615 & 0.625 & 0.840 & - & - & - & - & - & - \\
\hline Functional perception & 0.846 & 0.564 & 0.525 & 0.575 & 0.352 & 0.467 & 0.920 & - & - & - & - & - \\
\hline Symbolic perception & 0.678 & 0.509 & 0.488 & 0.527 & 0.452 & 0.444 & 0.703 & 0.772 & 0.823 & - & - & - \\
\hline Brand-self connection & 0.932 & 0.530 & 0.574 & 0.530 & 0.599 & 0.516 & 0.490 & 0.654 & 0.552 & 0.965 & - & - \\
\hline Brand prominence & 0.854 & 0.626 & 0.621 & 0.647 & 0.623 & 0.595 & 0.570 & 0.725 & 0.606 & 0.799 & 0.924 & - \\
\hline Purchase intention & 0.828 & 0.599 & 0.582 & 0.612 & 0.544 & 0.590 & 0.647 & 0.758 & 0.587 & 0.634 & 0.770 & 0.910 \\
\hline
\end{tabular}

$\mathrm{AVE}$, average variance extracted; SV, self-identify value; $\mathrm{MV}$, materialistic value; $\mathrm{HV}$, hedonic value; SI, strong ties influence; WI, weak ties influence; $\mathrm{FP}$, functional perception; $\mathrm{EP}$, experiential perception; SP, symbolic perception; BC, brand-self connection; $\mathrm{BP}$, brand prominence; $\mathrm{PI}$, purchase intention.

which indicates that individual value, social influence and luxury brand image can explain approximately $60 \%$ of the variance in brand attachment. The resultant R-squared for purchase intention as the dependent construct was 0.643, which indicates that the influence of brand attachment and luxury brand image on purchase intention accounts for $64.3 \%$ of the variance. In addition, the Sobel test (Baron \& Kenney 1986; Sobel 1982) was conducted separately to examine whether brand attachment mediates the relationship between the three antecedents (i.e. individual value, social influence and brand image) and purchase intention. The results showed that all the mediating effects of brand attachment are statistically significant. Moreover, a partial mediating effect of brand attachment on the relationship between luxury brand image and purchase intention was noted (Sobel's $z=5.2499, p<0.01$ ). 


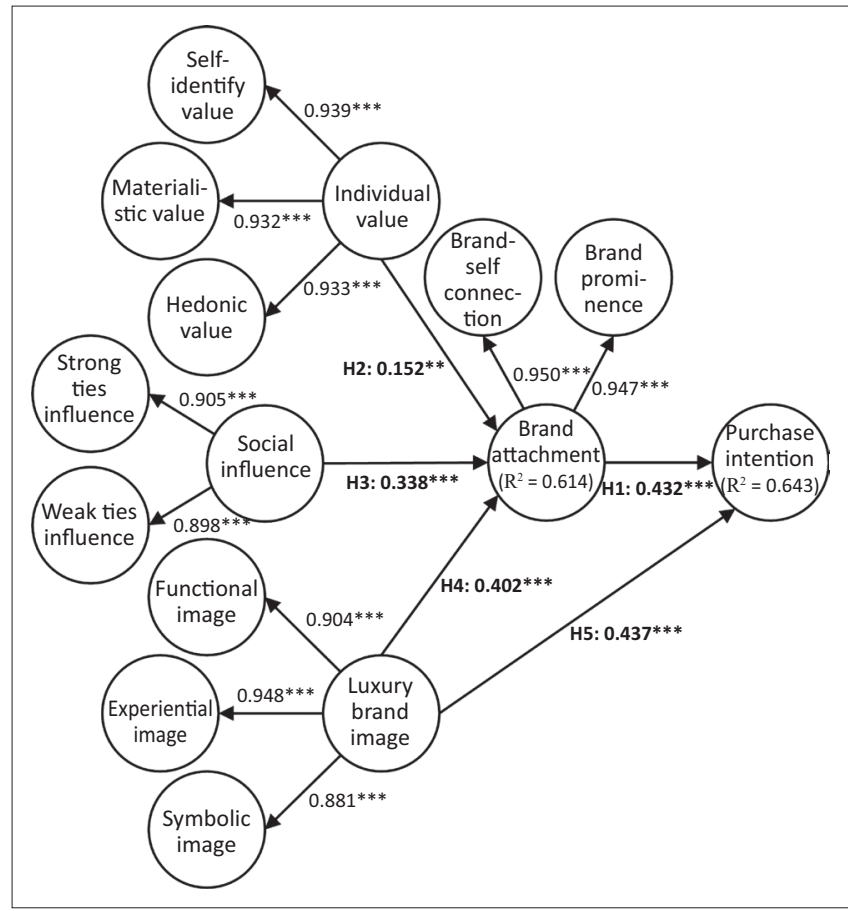

FIGURE 2: Partial least square regression results for the proposed research model.

TABLE 4: Subsample-specific assessment results.

\begin{tabular}{|c|c|c|c|c|}
\hline Latent variables & $\begin{array}{l}\text { Reliability } \\
\text { and validity }\end{array}$ & Taiwan & Hong Kong & China \\
\hline \multirow[t]{2}{*}{ Individual value } & $\mathrm{CR}$ & 0.942 & 0.943 & 0.942 \\
\hline & AVE & 0.700 & 0.704 & 0.700 \\
\hline \multirow[t]{2}{*}{ Social influence } & $\mathrm{CR}$ & 0.869 & 0.838 & 0.886 \\
\hline & AVE & 0.528 & 0.464 & 0.567 \\
\hline \multirow[t]{2}{*}{ Luxury brand image } & $\mathrm{CR}$ & 0.941 & 0.935 & 0.923 \\
\hline & AVE & 0.616 & 0.589 & 0.548 \\
\hline \multirow[t]{2}{*}{ Brand attachment } & $C R$ & 0.923 & 0.917 & 0.921 \\
\hline & AVE & 0.750 & 0.736 & 0.744 \\
\hline \multirow[t]{2}{*}{ Purchase intention } & $C R$ & 0.961 & 0.907 & 0.930 \\
\hline & AVE & 0.859 & 0.708 & 0.769 \\
\hline$n$ & - & 105 & 105 & 149 \\
\hline Path relationships & - & - & - & - \\
\hline $\begin{array}{l}\text { Individual value } \rightarrow \\
\text { Brand attachment }\end{array}$ & - & 0.192 & 0.130 & $0.285 * * *$ \\
\hline $\begin{array}{l}\text { Social influence } \rightarrow \\
\text { Brand attachment }\end{array}$ & - & $0.278 * * *$ & 0.099 & $0.431 * * *$ \\
\hline $\begin{array}{l}\text { Luxury brand image } \rightarrow \\
\text { Brand attachment }\end{array}$ & - & $0.409 * * *$ & $0.480 * * *$ & 0.123 \\
\hline $\begin{array}{l}\text { Brand attachment } \rightarrow \\
\text { Purchase intention }\end{array}$ & - & $0.594 * * *$ & $0.172 * *$ & $0.354 * * *$ \\
\hline $\begin{array}{l}\text { Luxury brand image } \rightarrow \\
\text { Purchase intention }\end{array}$ & - & $0.251 * * *$ & $0.531 * * *$ & $0.530 * * *$ \\
\hline$R^{2}$ & - & - & - & - \\
\hline Brand attachment & - & 0.590 & 0.377 & 0.546 \\
\hline Purchase intention & - & 0.623 & 0.419 & 0.594 \\
\hline
\end{tabular}

$\mathrm{CR}$, composite reliabilities; $\mathrm{AVE}$, average variance extracted.

$*$, Significance at $0.10 ; * *$, significance at $0.05 ; * *$, significance at 0.01

\section{Multi-group analysis}

Table 4 summarises the results of the structural model evaluation for the three subsamples. Specifically, the analyses per subsample show that all indicators exhibit loadings above 0.7, and AVE values of the variables are above 0.5 except the social influence of Hong Kong (AVE = 0.464). In addition, all constructs achieved high CR values of 0.8 and higher. In addition, the discriminate validity of the constructs for the three subsamples were assessed by examining the cross-loading of indicators (Hair, Ringle \& Sarstedt 2013) and Fornell and Lacker's (1981) criterion. Overall, these results indicate that the constructs exhibit sufficient reliability and construct validity.

From Table 4, in the Taiwan subsample, it can be observed that individual value does not display statistical significance with respect to brand attachment, and the path coefficients of other path relations are all significant. Among these coefficients, brand attachment is substantially influenced by luxury brand image, and brand attachment has a significant influence on purchase intention. Regarding the Hong Kong subsample, brand attachment and purchase intention are mainly affected by luxury brand image. Interestingly, individual value and social influence do not significantly influence brand attachment. The influence of brand attachment on purchase intention in Hong Kong is the lowest of the three areas. Regarding the China subsample, individual value and social influence have significant effects on brand attachment, and luxury brand image did not exhibit a statistical influence on brand attachment, although it appears to directly influence purchase intention.

Furthermore, we compared the area-specific path coefficients. The results reveal that individual value has the strongest effect on brand attachment in the China subsample; the estimated coefficient is 0.285 and displays statistical significance. Next, social influence displays significant influence on brand attachment throughout the Taiwan and China subsamples. China displays the highest positive influence, with a path coefficient of 0.431. Subsequently, luxury brand image displays a significant influence on brand attachment in the Taiwan and Hong Kong subsamples, with the path coefficient being the highest in Hong Kong (0.480). In addition, the elements that influence purchase intention include two antecedents: brand attachment and luxury brand image. All the three subsamples display positive influence, whereby brand attachment has the strongest effect on purchase intention in the Taiwan subsample and the weakest effect on the Hong Kong subsample. Regarding the influence of luxury brand image on purchase intention, the path coefficients of the Hong Kong and China subsamples are similar (0.531 and 0.530, respectively) and are much higher than that of the Taiwan subsample (a path coefficient of 0.251 ).

Furthermore, the mediating role of brand attachment was evaluated for each subsample using the Sobel test (Baron \& Kenney 1986; MacKinnon, Warsi \& Dwyer 1995). The results indicated that in the Taiwan subsample, brand attachment has a partial mediating effect on the relationship between brand image and purchase intention (Sobel's $z=3.3992$, $p<0.01$ ). Moreover, the relationship between social influence and purchase intention is mediated by brand attachment in both the Taiwan (Sobel's $\mathrm{z}=2.5583, p<0.05$ ) and China subsamples (Sobel's $z=2.5269, p<0.05$ ). Finally, the results 
TABLE 5: Multi-group comparison test results.

\begin{tabular}{llcc}
\hline Relationship & Comparison & $\begin{array}{c}\text { Path Coefficients- } \\
\text { diff (I diff I) }\end{array}$ & t(Parametric) \\
\hline Individual value $\rightarrow$ & TW versus HK & 0.062 & 0.348 \\
Brand attachment & TW versus CN & 0.093 & 0.537 \\
& HK versus CN & 0.155 & 1.000 \\
Social influence $\rightarrow$ & TW versus HK & 0.179 & 1.258 \\
Brand attachment & TW versus CN & 0.153 & 1.131 \\
& HK versus CN & 0.332 & $2.447^{* *}$ \\
Luxury brand image $\rightarrow$ & TW versus HK & 0.071 & 0.527 \\
Brand attachment & TW versus CN & 0.286 & 1.618 \\
& HK versus CN & 0.357 & $2.164^{* *}$ \\
Brand attachment $\rightarrow$ & TW versus HK & 0.423 & $3.477^{* * *}$ \\
Purchase intention & TW versus CN & 0.241 & 1.582 \\
& HK versus CN & 0.182 & 1.117 \\
Luxury brand image $\rightarrow$ & TW versus HK & 0.280 & $2.284^{* *}$ \\
Purchase intention & TW versus CN & 0.279 & $2.324^{* *}$ \\
& HK versus CN & 0.001 & 0.007 \\
\hline
\end{tabular}

TW, Taiwan; HK, Hong Kong; CN, China.

$*$, Significance at $0.10 ; * *$, significance at $0.05 ; * *$, significance at 0.01 .

showed that the relationship between individual value and purchase intention is mediated by brand attachment only in the China subsample (Sobel's $z=2.0050, p<0.05$ ).

Table 5 shows the differences among the path coefficient estimates (Taiwan vs. Hong Kong, Taiwan vs. China and Hong Kong vs. China) and provides the results of the multigroup comparisons based on a parametric approach (Keil et al. 2000). Firstly, there is no significant difference in the relationship of individual value and brand attachment across the three subsamples. Secondly, the results indicate a significant difference between the Hong Kong and China subsamples in terms of social influence and brand attachment relationship. The difference between the two path coefficients is 0.332. Thirdly, regarding the path coefficients in the relationship of luxury brand image and brand attachment, there is a significant difference between the Hong Kong and China subsamples.

Regarding the path relation of brand attachment to purchase intention, Taiwan's path coefficient of 0.594 is significantly higher than Hong Kong's 0.172. In addition, regarding the relationship between luxury brand image and purchase intention, the path coefficient of the Taiwan subsample significantly differs from that of the Hong Kong and China subsamples. The path coefficients of Hong Kong and China subsamples are similar and indicate no significant difference.

\section{Discussion}

For consumers in Greater China, the research constructs in this study (i.e. individual value, social influence and luxury brand image) positively influence brand attachment. In addition, brand attachment and luxury brand image positively influence purchase intention, which confirms the research model and hypotheses proposed in this study. In addition, the R-squared of both brand attachment and purchase intention is above 0.6 , thus providing a high degree of explanatory power.
The following is a multi-group comparison analysis of path coefficients among the three groups in Greater China. Firstly, main differences between China and Hong Kong can be observed in the path relations between social influence and brand attachment. The path coefficient of the China subsample is significantly higher than that of the Hong Kong subsample. However, a significant difference can be observed: the strongest influence of luxury brand image on brand attachment was witnessed in the Hong Kong subsample. Based on our results, it can be inferred that consumer attachment to luxury brands in China is more likely to be influenced by external information. In contrast, the formation of brand attachment among Hong Kong consumers is primarily caused by consumers' perception of the brand because the brand image is mainly constructed by the rational perception of a brand's functional, experiential and symbolic aspects.

When Taiwan is compared with Hong Kong, purchase intention was strongly influenced by brand attachment in the Taiwan subsample, whereas in the Hong Kong subsample, luxury brand image exerts the primary influence on purchase intention. The results reveal that the affection for a luxury brand is the dominant factor with respect to purchase intention among Taiwan consumers, whereas the purchase intention of Hong Kong consumers is less affected by brand attachment. Finally, in the comparison between the Taiwan and China subsamples, luxury brand image is a significant element that influences purchase intention for Chinese consumers. The purchase intention of Taiwanese consumers is less affected by luxury brand image.

The reasons for the preceding results are considered as follows. Firstly, Chinese culture is group-oriented, and the Chinese tend to believe in collectivism. In addition, vanity is a major motivator to purchase luxury brands, and the social function of luxury is even higher among Chinese consumers; thus, the establishment of brand attachment is strongly influenced by the views and opinions of others. Moreover, the rapid development of e-commerce and the prevalence of the Internet enhance the reference to and the use of external information among Chinese consumers.

Within Greater China, Hong Kong is a metropolis wherein many luxury brands have emerged, producing a mature luxury market. Notably, Hong Kong consumers tend to have a more rational attitude towards luxury consumption, and their brand cognition and affection are primarily founded on the brand image perceived by consumers themselves. As for Taiwan, the luxury market is very active, and Taiwanese consumers are familiar with luxury brand consumption (although the history and number of luxury brands introduced in Taiwan are far shorter and smaller than in Hong Kong). Overall, the purchasing preferences of Taiwanese consumers are prone to specific major luxury brands. Thus, their attitudes towards luxury brands are more heavily based on the familiarity and trust associated with a brand, which has led to the relatively high influence of brand 
attachment on purchase intention. In summary, the attitude of consumers towards luxury brands in the three areas of Greater China can be characterised as follows: Hong Kong consumers are the most rational regarding luxury brand consumption; Taiwanese consumers are more influenced by affection for the luxury brand and Chinese consumers mainly depend on external references.

\section{Conclusion and implication}

In conclusion, a brand image can strengthen a consumer's purchase intention, and the creation of brand attachment would obtain long-term profits and avoid losing customers to competitors. In addition, a brand attachment represents an effective connection between customers and brands. In contrast, a brand image concerns the rational perception of a brand. In practical terms, a marketing suggestion for the Taiwanese market would be to improve brand image by optimising quality, design and service to effectively strengthen the brand attachment. Furthermore, we could infer that Taiwanese consumers have relatively higher loyalty to familiar and beloved brands. Therefore, for luxury brands, maintaining a relationship with regular and existing customers will make profits sustainable. Regarding Hong Kong consumers, their purchase behaviours are strongly affected by the perception of luxury brand image. We recommend that brands should seek to attract this morerational group through enhancing brand image by providing originality and superior quality. Regarding the Chinese market because consumers are more likely influenced by external references, investing resources in marketing programmes, such as by intensifying social community operations and enhancing word-of-mouth marketing, may benefit the building of brand attachment. This approach may also be beneficial with respect to acquiring new customers for brands.

Unlike regular consumer goods, luxury brands and their products have groups of enthusiasts with strong value identification regarding their consumption. Earlier studies primarily examined luxury brand types, consumer segmentation and the consumption behaviour of consumers (Dubois \& Duquesne 1993; Gao et al. 2009; Li et al. 2012; Wang et al. 2010). The aim of this study was to fill the gap in the literature by evaluating the mediating effect of brand attachment and examining this influence from individual, social and brand cognition perspectives. Another contribution of this study is that it provides a comparative analysis of the Chinese market, thereby enhancing the understanding of consumers' perceptions and behaviours related to luxury brands in China, Hong Kong and Taiwan ('Greater China'). For Chinese consumers, traditional Chinese culture causes social influence to have a more powerful effect on luxury brand consumption than individual values such as selfidentity and material needs, thereby differentiating them from Western consumers (Wong \& Ahuvia 1998). Furthermore, the knowledge of luxury brands, and familiarity with them, can increase consumers' rationality regarding luxury brand consumption, counteracting social influences and enhancing their decision-making, particularly in developed markets. This indicates that, in addition to its social and cultural effects, the degree to which the luxury brand industry has developed plays an important role.

In this study, we examined the effects of individual value, social influence and brand image on brand attachment and purchase intention towards luxury brands. However, future research can explore the moderating effect of constructs in the proposed model (e.g. individual value and social influence as moderators of the relationship between brand image and brand attachment). Moreover, the results of the present study are based on a comparative analysis of consumers in Greater China; future research should extend its samples to other emerging markets of luxury brand consumption in Asia (e.g. Southeast Asia) to identify and understand the characteristics of diverse consumers.

\section{Acknowledgements Competing interests}

The authors declare that they have no financial or personal relationship(s) that may have inappropriately influenced them in writing this article.

\section{Authors' contributions}

T-H.K. is an assistant professor in the Department of Textile and Clothing at $\mathrm{Fu}$ Jen Catholic University. His research interests include fashion marketing, brand management, Internet marketing and e-commerce, and textile science. T-H.K. made the conceptulisation, wrote the first draft of the article, performed data analytics, edited the manuscript and guided the research. T-L.L. received her master's degree from the Department of Textile and Clothing at Fu Jen Catholic University. Her research has been focused on brand management, fashion marketing and Internet marketing. T-L.L. made literature review, survey data collection and calculation, and recommendation.

\section{References}

Ahluwalia, R., Burnkrant, R.E. \& Unnava, H.R., 2000, 'Consumer response to negative publicity: The moderating role of commitment', Journal of Marketing Research $37(2), 203-214$.

Akçura, T.M., Gönül, F.F. \& Petrova, E., 2004, 'Consumer learning and brand valuation: An application on over-the-counter drugs', Marketing Science 23(1), 156-169.

Barclay, D., Higgins, C. \& Thompson, R., 1995, 'The partial least squares (PLS) approach to causal modeling: Personal computer adoption and use as an illustration', Technology Studies 2(2), 285-309.

Baron, R.M. \& Kenny, D.A., 1986, 'The moderator-mediator variable distinction in social psychological research: Conceptual, strategic, and statistical considerations', Journal of Personality and Social Psychology 51(6), 1173-1182. https://doi. org/10.1037/0022-3514.51.6.1173

Berthon, P., Pitt, L., Parent, M. \& Berthon, J.P., 2009, 'Aesthetics and ephemerality: Observing and preserving the luxury brand', California Management Review 52(1), 45-66. https://doi.org/10.1525/cmr.2009.52.1.45

Bowlby, J., 1982, 'Attachment and loss: Retrospect and prospect', American Journal of Orthopsychiatry 52(4), 664-678. https://doi.org/10.1111/j.1939-0025.1982. tb01456.x

Brown, J.J. \& Reingen, P.H., 1987, 'Social ties and word-of-mouth referral behavior', Journal of Consumer Research 14(3), 350-362. https://doi.org/10.1086/209118

Carroll, B.A. \& Ahuvia, A.C., 2006, 'Some antecedents and outcomes of brand love', Marketing Letters 17(2), 79-89. https://doi.org/10.1007/s11002-006-4219-2 
Chaplin, L.N. \& John, D.R., 2005, 'The development of self-brand connections in children and adolescents', Journal of Consumer Research 32(1), 119-129. https:// doi.org/10.1086/426622

Chin, W.W., 1998, 'The partial least squares approach to structural equation modeling', in G.A. Marcoulides (ed.), Modern methods for business research, pp. 295-336, Lawrence Erlbaum, Mahwah, NJ.

Dubois, B. \& Duquesne, P., 1993, 'The market for luxury goods: Income versus culture', European Journal of Marketing 27(1), 35-44. https://doi.org/10.1108/ 03090569310024530

Fornell, C. \& Bookstein, F.L., 1982, 'Two structural equation models: LISREL and PLS applied to consumer exit-voice theory', Journal of Marketing Research 19(4), 440-452. https://doi.org/10.2307/3151718

Fornell, C. \& Cha, J., 1994, 'Partial least squares', in R.P. Bagozzi (ed.), Advanced methods of marketing research, pp. 52-78, Blackwell Publishers, Oxford.

Fornell, C. \& Larcker, D.F., 1981, 'Evaluating structural equation models with unobserved variables and measurement error', Journal of Marketing Research 18(1), 39-50. https://doi.org/10.2307/3151312

Gao, L., Norton, M.J., Zhang, Z.M. \& To, C.K., 2009, 'Potential niche markets for luxury fashion goods in China', Journal of Fashion Marketing and Management 13(4), 514-526. https://doi.org/10.1108/13612020910991376

Gefen, D. \& Straub, D., 2005, 'A practical guide to factorial validity using PLS-Graph: Tutorial and annotated example', Communications of the Association for Information systems 16(1), 91-109.

Grewal, D., Monroe, K.B. \& Krishnan, R., 1998, 'The effects of price-comparison advertising on buyers' perceptions of acquisition value, transaction value, and behavioral intentions', Journal of Marketing 62(2), 46-59. https://doi.org/ $10.2307 / 1252160$

Hair, J.F., Black, W.C., Babin, B.J. \& Abderson, R.E., 2009, Multivariate data analysis, 7 th edn., Prentice Hall, Upper Saddle River, NJ.

Hair, J.F., Ringle, C.M. \& Sarstedt, M., 2013, 'Editorial-partial least squares structural equation modeling: Rigorous applications, better results and higher acceptance' Long Range Planning 46(1-2), 1-12. https://doi.org/10.1016/j.Irp.2013.01.001

Hennigs, N., Wiedmann, K.P., Klarmann, C., Strehlau, S., Godey, B., Pederzoli, D. et al., 2012, "What is the value of luxury? A cross-cultural consumer perspective' Psychology \& Marketing 29(12), 1018-1034. https://doi.org/10.1002/mar.20583

Hulland, J., 1999, 'Use of partial least squares (PLS) in strategic management research: A review of four recent studies', Strategic Management Journal 20(2), 195-204. https://doi.org/10.1002/(SICI)1097-0266(199902)20:2\%3C195::AID-SMJ13\% https://doi.org/
3E3.0.CO;2-7

Hung, K.P., Chen, A.H., Peng, N., Hackley, C., Tiwsakul, R.A. \& Chou, C.L., 2011 'Antecedents of luxury brand purchase intention', Journal of Product \& Brand Management 20(6), 457-467. https://doi.org/10.1108/10610421111166603

Keil, M., Tan, B.C.Y., Wei, K.K., Saarinen, T., Tuunainen, V. \& Wassenaar, A., 2000, 'A cross-cultural study on escalation of commitment behavior in software projects', Management Information Systems Quarterly 24(2), 299-325. https:// doi.org/10.2307/3250940

Keller, K.L., 1993, 'Conceptualizing, measuring, and managing customer-based brand equity', Journal of Marketing 57(1), 1-22. https://doi.org/10.2307/1252054

Li, G., Li, G. \& Kambele, Z., 2012, 'Luxury fashion brand consumers in China: Perceived value, fashion lifestyle, and willingness to pay', Journal of Business Research 65(10), 1516-1522. https://doi.org/10.1016/j.jbusres.2011.10.019

MacKinnon, D.P., Warsi, G. \& Dwyer, J.H., 1995, 'A simulation study of mediated effect measures', Multivariate Behavioral Research 30(1), 41-62. https://doi.org/ 10.1207/s15327906mbr3001_3
Mitchell, J.C., 1969, Social networks in Urban Situations, Manchester University Press, Manchester.

Park, C.W., Jaworski, B.J. \& Maclnnis, D.J., 1986, 'Strategic brand concept-image management', The Journal of Marketing 50(4), 135-145. https://doi.org/10.2307/ 1251291

Park, C.W., MacInnis, D.J. \& Priester, J., 2006, 'Brand attachment: Constructs, consequences, and causes', Foundations and Trends in Marketing 1(3), 191-230. https://doi.org/10.1561/1700000006

Park, C.W., MacInnis, D.J., Priester, J., Eisingerich, A.B. \& lacobucci, D., 2010, 'Brand attachment and brand attitude strength: Conceptual and empirical differentiation of two critical brand equity drivers', Journal of Marketing 74(6), 1-17. https://doi. org/10.1509/jmkg.74.6.1

Park, C.W., Priester, J.R., MacInnis, D.J. \& Wan, Z., 2009, 'The connection-prominence attachment model (CPAM): A conceptual and methodological exploration of brand attachment', in D.J. Maclnnis, C.W. Park \& J.R. Priester (eds.), Handbook of brand relationships, pp. 327-341, M.E. Sharpe, New York.

Sallot, L.M., 2002, 'What the public thinks about public relations: An impression management experiment', Journalism \& Mass Communication Quarterly 79(1), 150-172. https://doi.org/10.1177/107769900207900111

Schlosser, A.E., White, T.B. \& Lloyd, S.M., 2006, 'Converting web site visitors into buyers: How web site investment increases consumer trusting beliefs and online purchase intentions', Journal of Marketing 70(2), 133-148. https://doi.org/ purchase intentions',
$10.1509 /$ jmkg.70.2.133

Sobel, M.E., 1982, 'Asymptotic confidence intervals for indirect effects in structural equations models', in S. Leinhart (ed.), Sociological methodology, pp. 290-312, Jossey-Bass, San Francisco, CA.

Thomson, M., MacInnis, D.J. \& Park, C.W., 2005, 'The ties that bind: Measuring the strength of consumers' emotional attachments to brands', Journal of Consumer Psychology 15(1), 77-91. https://doi.org/10.1207/s15327663jcp1501_10

Vigneron, F. \& Johnson, L.W., 1999, 'A review and a conceptual framework of prestigeseeking consumer behavior', Academy of Marketing Science Review 1999(1) $1-17$.

Vigneron, F. \& Johnson, L.W., 2004, 'Measuring perception of brand luxury', Journal of Brand Management 11(6), 484-506. https://doi.org/10.1057/palgrave.bm.2540194

Wang, Y., Sun, S. \& Song, Y., 'Motivation for luxury consumption: Evidence from a metropolitan city in China', Research in Consumer Behavior 12, 161-181.

Weiss, R.S., 1988, 'Loss and recovery', Journal of Social Issues 44(3), 37-52. https:// doi.org/10.1111/j.1540-4560.1988.tb02075.x

Wiedmann, K.P., Hennigs, N. \& Klarmann, C., 2012, 'Luxury consumption in the tradeoff between genuine and counterfeit goods: What are the consumers underlying motives and value-based drivers?', Journal of Brand Management 19(7), 544-566. https://doi.org/10.1057/bm.2012.10

Wiedmann, K.P., Hennigs, N. \& Siebels, A., 2009, 'Value-based segmentation of luxury consumption behavior', Psychology \& Marketing, 26(7), 625-651.

Wirtz, J. \& Chew, P., 2002, 'The effects of incentives deal proneness, satisfaction and tie strength on word-of-mouth behavior', International Journal of Service Industry Management 13(2), 141-162. https://doi.org/10.1108/09564230210425340

Wong, N.Y. \& Ahuvia, A.C., 1998, 'Personal taste and family face: Luxury consumption in Confucian and Western societies', Psychology \& Marketing 15(5), 423-441. https://doi.org/10.1002/(SICI)1520-6793(199808)15:5\%3C423::AID-MAR2\% 3E3.0.CO;2-9

Zeithaml, V.A., 1988, 'Consumer perceptions of price, quality, and value: A means-end model and synthesis of evidence', Journal of Marketing 52(3), 2-22. https://doi. org/10.2307/1251446 